\title{
More on Finance and Growth: More Finance, More Growth?
}

\author{
Ross Levine
}

$\mathbf{N}$ obel Prize winners disagree about the impact of the financial sector on economic growth. Some do not even consider finance worth discussing. A collection of essays by the "pioneers of development economics"-including three winners of the Nobel Prize in Economics-does not discuss finance (Meier and Seers, 1984). At the other extreme, Nobel Prize winner Merton Miller (1998, p. 14) recently remarked "that financial markets contribute to economic growth is a proposition almost too obvious for serious discussion." As a third view, Nobel Laureate Robert Lucas (1988) holds that the role of finance in economic growth has been "over-stressed" by the growth literature. Resolving the debate about the importance of financial development for economic growth is important for distinguishing among theoretical models. More importantly, information on the importance of finance for growth will affect the intensity with which researchers and policymakers attempt to identify and construct appropriate financial sector reforms around the world.

This paper selectively discusses recent empirical work on the controversial issue of whether financial systems play a critical role in determining long-run rates of economic growth. Building on work by Bagehot (1873), Schumpeter (1912), Gurley and Shaw (1955), Goldsmith (1969), and McKinnon (1973), recent research has employed different econometric methodologies and data sets to assess the role of the financial sector in stimulating economic growth. I will focus on three classes of empirical studies: (i) pure cross-country growth regressions, (ii) panel techniques that exploit both the cross-country and time-series dimensions of the data, and (iii) microeconomic-based studies that examine the mechanisms through which finance may influence economic growth. Thus, I will largely ignore country case studies and purely time-series investigations, which generally confirm the conclusions from the

Ross Levine holds the Curtis L. Carlson Chair of Finance at the University of Minnesota. The author thanks Luigi Zingales for helpful comments.

(1) 2003, The Federal Reserve Bank of St. Louis. cross-country, panel, and microeconomic-based studies. Also, this paper does not discuss the theory surrounding the role of financial contracts, markets, and intermediaries in economic growth. ${ }^{1}$

The growing body of empirical research, using different statistical procedures and data sets, produces remarkably consistent results. First, countries with better-developed financial systems tend to grow faster-specifically, those with (i) large, privately owned banks that funnel credit to private enterprises and (ii) liquid stock exchanges. The levels of banking development and stock market liquidity each exert a positive influence on economic growth. Second, simultaneity bias does not seem to be the cause of this result. Third, better-functioning financial systems ease the external financing constraints that impede firm and industrial expansion. Thus, access to external capital is one channel through which financial development matters for growth because it allows financially constrained firms to expand.

Each of the different statistical procedures that have been brought to bear on the finance-growth debate has methodological shortcomings, which emphasizes the need for additional research to clarify the relationship between finance and growth. Moreover, data problems plague the study of finance and growth in general. Perhaps the biggest data problem involves the empirical proxies of "financial development," because it is difficult to construct accurate, consistent measures of financial development for a broad cross-section of countries. Thus, more microeconomic-based studies that explore the possible channels through which finance influences growth will foster a keener understanding of the finance-growth nexus. Without ignoring the weaknesses of existing work and the need for future research, the consistency of existing empirical results across different data sets and statistical procedures suggests that finance plays an important role in the process of economic growth.

The body of existing work motivates research

\footnotetext{
1 For a review of the theory of finance and growth and a discussion of the time-series and case-study literature, see Levine (1997 and 2002a).
} 
Table 1

\section{Growth and Financial Intermediary Development, 1960-89}

\begin{tabular}{lccc} 
& \multicolumn{2}{c}{ Dependent variables } \\
\cline { 2 - 4 } & $\begin{array}{c}\text { Real per capita } \\
\text { GDP growth }\end{array}$ & $\begin{array}{c}\text { Real per capita } \\
\text { capital growth }\end{array}$ & Productivity growth \\
\hline DEPTH & $2.4^{* *}$ & $2.2^{* *}$ & $1.8^{* *}$ \\
$\mathrm{R}^{2}$ & $(0.007)$ & $(0.006)$ & $(0.026)$ \\
& 0.50 & 0.65 & 0.42
\end{tabular}

NOTE: Observations: 77.

**Indicates significance at the 5 percent level; $\mathrm{p}$-values are in parentheses.

Variable definitions: DEPTH = liquid liabilities/GDP; productivity growth $=$ real per capita GDP growth $-(0.3) *($ real per capita capital growth). Other explanatory variables included in each of the nine regression results reported above: logarithm of intial income, logarithm of initial secondary school enrollment, ratio of government consumption expenditures to GDP, inflation rate, and ratio of exports plus imports to GDP.

King and Levine (1993b) define 2 percent growth as 0.02. For comparability with subsequent tables, we have redefined 2 percent growth as 2.00 and adjusted the coefficients by a factor of 100 .

SOURCE: King and Levine (1993b, Table VII).

into the determinants of financial development. If financial development is crucial for growth, how can countries develop well-functioning financial systems? What legal, regulatory, and policy changes would foster the emergence of growth-enhancing financial markets and intermediaries? While I do not discuss this emerging literature, I point to some recent work on this question in the conclusion.

The remainder of the paper proceeds as follows. The next section discusses cross-country studies of growth. The third section reviews panel studies of growth, and the fourth section analyzes industryand firm-level research on the finance-growth nexus.

\section{CROSS-COUNTRY STUDIES}

\section{Financial Intermediaries and Growth}

I first examine the application of broad crosscountry growth regressions to the study of finance and growth. These studies aggregate economic growth over long periods, a decade or more, and assess the relationship between long-run growth and measures of financial development. King and Levine (1993a,b,c) build on earlier cross-country work by Goldsmith (1969). In particular, King and Levine (1993a,b,c) more than double Goldsmith's (1969) sample of countries, study growth over a 30-year horizon, and systematically control for many possible determinants of economic growth such as initial income, educational attainment, inflation, black market exchange rate premia, government spending, openness to trade, and political instability. Furthermore, they examine whether financial development is associated with productivity growth and capital accumulation, which are two channels through which finance may influence economic growth.

King and Levine (1993b) (henceforth KL) study 77 countries over the period 1960-89. To measure financial development, KL focus on DEPTH, which equals the size of the financial intermediary sector. It equals the liquid liabilities of the financial system (currency plus demand and interest-bearing liabilities of banks and nonbank financial intermediaries) divided by gross domestic product (GDP). An important weakness of this measure of financial development is that DEPTH measures the size of the financial intermediary sector. It may not, however, represent an accurate proxy for the functioning of the financial system. It may not proxy for how well bank research firms exert corporate control or provide risk management services to clients. KL experiment with alternative measures of financial development that are designed to gauge who is conducting credit allocation, i.e., whether it is banks or the government, and to where the credit is flowing, i.e., to the private sector or to the government and state-owned enterprises. They obtain similar results with these alternative indicators of financial development (also see La Porta, Lopez-de-Silanes, and Shleifer, 2002). 


\section{Table 2}

\section{Growth and Initial Financial Depth, 1960-89}

\begin{tabular}{lccc} 
& \multicolumn{2}{c}{ Dependent variables } \\
\cline { 2 - 4 } & $\begin{array}{c}\text { Real per capita } \\
\text { GDP growth }\end{array}$ & $\begin{array}{c}\text { Real per capita } \\
\text { capital growth }\end{array}$ & Productivity growth \\
\hline DEPTH & $2.8^{* *}$ & $1.9^{* *}$ & $2.2^{* *}$ \\
$\mathrm{R}^{2}$ & $(0.001)$ & $(0.001)$ & $(0.001)$ \\
& 0.61 & 0.63 & 0.58
\end{tabular}

NOTE: Observations: 57.

**Indicates significance at the 5 percent level; $\mathrm{p}$-values are in parentheses.

Variable definitions: DEPTH = liquid liabilities/GDP; productivity growth $=$ real per capita GDP growth $-(0.3) *($ real per capita capital growth). Other explanatory variables included in each of the nine regression results reported above: logarithm of intial income, logarithm of initial secondary school enrollment, ratio of government consumption expenditures to GDP, inflation rate, and ratio of exports plus imports to GDP.

King and Levine (1993b) define 2 percent growth as 0.02 . For comparability with subsequent tables, we have redefined 2 percent growth as 2.00 and adjusted the coefficients by a factor of 100.

SOURCE: King and Levine (1993b, Table VII) and Levine (1997, Table 3).

KL assess the strength of the empirical relationship between DEPTH averaged over the 1960-89 period and three growth indicators also averaged over the same period, $G$. The three growth indicators are as follows: (i) the average rate of real per capita GDP growth, (ii) the average rate of growth in the capital stock per person, and (iii) total productivity growth, which is a "Solow residual" defined as real per capita GDP growth minus (0.3) times the growth rate of the capital stock per person. The analyses include a matrix of conditioning information, $X$, that controls for other factors associated with economic growth (e.g., income per capita, education, political stability, indicators of exchange rate, trade, fiscal, and monetary policy). KL estimated the following regressions:

$$
G_{j}=a+b \mathrm{DEPTH}+c X+u .
$$

Adapted from KL, Table 1 indicates that there is a statistically significant and economically large relationship between DEPTH and (i) long-run real per capita growth, (ii) capital accumulation, and (iii) productivity growth. The coefficient on DEPTH implies that a country that increased DEPTH from the mean of the slowest growing quartile of countries $(0.2)$ to the mean of the fastest growing quartile of countries (0.6) would have increased its per capita growth rate by almost 1 percent per year. This is large. The difference between the slowest growing 25 percent of countries and the fastest growing 25 percent of countries is about 5 percent per annum over this 30-year period. Thus, the rise in DEPTH alone eliminates 20 percent of this growth difference. The illustrative example, however, ignores causality and the issue of how to increase DEPTH.

$\mathrm{KL}$ also examine whether the value of financial depth in 1960 predicts the rate of economic growth, capital accumulation, and productivity growth over the next 30 years. As shown in Table 2, the regressions indicate that financial depth in 1960 is a good predictor of subsequent rates of economic growth, physical capital accumulation, and economic efficiency improvements over the next 30 years, even after controlling for income, education, and measures of monetary, trade, and fiscal policy. Thus, finance does not simply follow growth; financial development predicts long-run growth.

While improving on past work, there are problems with methodology and interpretation in the $\mathrm{KL}$ analyses. As noted in the introduction, the proxy measures for financial development, DEPTH and the alternative measures, do not directly measure the ability of the financial system to (i) overcome information asymmetries and funnel credit to worthy firms, (ii) monitor managers effectively and exert corporate governance efficiently, (iii) provide risk management services, or (iv) facilitate exchange and the pooling of savings. This lowers the confidence one has in interpreting the results as establishing a link running from financial development to econ- 
omic growth. Also, while KL show that finance predicts growth, they do not deal formally with the issue of causality. Finally, KL focus on only one segment of the financial system-banks. They do not incorporate measures of other components of national financial systems.

\section{Stock Markets, Banks, and Economic Growth}

Following Atje and Jovanovic (1993), Levine and Zervos (1998) (henceforth LZ) add measures of stock market and banking development to crosscountry studies of growth. Thus, they simultaneously examine two components of the financial system: banks and equity markets. This provides information on the independent impact of stock markets and banks on economic growth. Thus, these analyses help policymakers set reform priorities and influence debates on the comparative importance of different segments of the financial sector (Demirgüç-Kunt and Levine, 2001).

LZ construct numerous measures of stock market development to assess the relationship between stock market development and economic growth, capital accumulation, and productivity. In this paper, I focus on one of the LZ liquidity indicators: the turnover ratio. This equals the total value of shares traded on a country's stock exchanges divided by stock market capitalization (the value of listed shares on the country's exchanges). The turnover ratio measures trading relative to the size of the market. All else equal, therefore, differences in trading frictions will influence the turnover ratio. LZ confirm their results using an assortment of stock market development indicators. ${ }^{2}$

There are difficulties in measuring liquidity, however. First, LZ do not measure the direct costs of conducting equity transactions. LZ simply measure trading, which may reflect differences in the arrival of news and how heterogeneous agents interpret this information. Thus, while we would like a

\footnotetext{
2 LZ (1998) examine three additional measures of liquidity. First, the value-traded ratio equals the total value of domestic stocks traded on domestic exchanges as a share of GDP. This measures trading relative to the size of the economy. The next two measures of liquidity measure trading relative to stock price movements: (i) the value-traded ratio divided by stock return volatility and (ii) the turnover ratio divided by stock return volatility. They also examine a measure of stock market integration. While a vast literature examines the pricing of risk, there exists very little empirical evidence that directly links risk diversification services with long-run economic growth. LZ do not find a strong link between economic growth and the ability of investors to diversify risk internationally.
}

proxy of the ease of trading at posted prices, the data provide only a measure of actual transactions. Second, stock markets may do more than provide liquidity. For instance, stock markets may provide mechanisms for hedging and trading the idiosyncratic risk associated with individual projects, firms, industries, sectors, and countries. Thus, focusing on liquidity may omit important services provided by equity markets and, therefore, mis-measure stock market development. Third, the turnover ratio measures domestic stock transactions on a country's national stock exchanges. The physical location of the stock market, however, may not necessarily matter for the provision of liquidity. This measurement problem will increase if economies become more financially integrated and firms list and issue shares on foreign exchanges.

Recent evidence, however, suggests that focusing on domestic financial markets is relevant. Guiso, Sapienza, and Zingales (2002) study the effects of differences in local financial development within an integrated financial market, Italy. They find that local financial development (i) enhances the probability an individual starts his own business, (ii) increases competition, and (iii) promotes the growth of firms. As predicted by theory, these effects are weaker for larger firms, which can more easily raise funds outside of the local area. Thus, the authors' results suggest that local financial development is an important determinant of the economic success of an area even in an environment where there are no frictions to capital movements.

The turnover ratio exhibits substantial crosscountry variability. Very active markets such as Japan and the United States had turnover ratios of almost 0.5 during the period 1976-93. Markets that are less liquid, such as Bangladesh, Chile, and Egypt, had turnover ratios of 0.06 or less.

As summarized in Table 3, LZ find that the initial level of stock market liquidity and the initial level of banking development (bank credit) are positively and significantly correlated with future rates of economic growth, capital accumulation, and productivity growth over the next 18 years, even after controlling for initial income, schooling, inflation, government spending, the black market exchange rate premium, and political stability. To measure banking sector development, LZ use bank credit, which they define as bank credit to the private sector as a share of GDP. This measure of banking development excludes credit issued by the government and the central bank and excludes credits issued to the 


\section{Table 3}

\section{Stock Market and Bank Development Predict Growth, 1976-93}

\begin{tabular}{lccc} 
& & & Independent variables (1976) \\
\cline { 2 - 4 } Dependent variables (1976-93) & Bank credit & Turnover & $\mathrm{R}^{2}$ \\
\hline Real per capita GDP growth & $1.31^{* *}$ & $2.69^{* *}$ & 0.50 \\
Real per capita capital growth & $(0.022)$ & $(0.005)$ & $2.22^{* *}$ \\
Productivity growth & $1.48^{* *}$ & $(0.024)$ & 0.51 \\
& $(0.025)$ & $2.01^{* *}$ & 0.40
\end{tabular}

NOTE: Observations: 42 for the real per capita GDP growth regression and 41 for the others.

**Indicates significance at the 5 percent level; $p$-values are in parentheses.

Variable definitions: Bank credit = bank credit to the private sector as a share of GDP in 1976 or the closest date with data; turnover $=$ value of the trades of domestic shares on domestic exchanges as a share of market capitalization of domestic shares in 1976 or the closest date with data; productivity growth $=$ real per capita GDP growth $-(0.3) *$ (real per capita capital growth). Other explanatory variables included in each of the regression results reported above: logarithm of intial income, logarithm of initial secondary school enrollment, ratio of government consumption expenditures to GDP, inflation rate, black market exchange rate premium, and frequency of revolutions and coups.

Levine and Zervos (1998) define 2 percent growth as 0.02 . For comparability with subsequent tables, we have redefined 2 percent growth as 2.00 and adjusted the coefficients by a factor of 100 .

SOURCE: Levine and Zervos (1998, Table 3).

government and public enterprises. LZ argue that their banking development indicator is better than KL's because nongovernmental financial intermediaries that are allocating credit to private firms are more likely to improve the efficiency of credit allocation and the monitoring of firms than intermediaries that allocate money to the government and public enterprises.

These results are consistent with models that emphasize that stock market liquidity facilitates long-run growth (Levine, 1991; Bencivenga, Smith, and Starr, 1995) and are not supportive of models that emphasize the negative aspects of stock market liquidity (Bhide, 1993). Furthermore, the results do lend much support to models that emphasize the tensions between bank-based and market-based systems. The results suggest that stock markets provide different financial functions from those provided by banks, or else they would not both enter the growth regression significantly.

The sizes of the coefficients are economically meaningful. For example, the estimated coefficient implies that a one-standard-deviation increase in initial stock market liquidity (0.30) would increase per capita GDP growth by 0.80 percentage points per year $\left(2.7^{*} 0.3\right)$. Accumulating over 18 years, this implies real GDP per capita would have been over 15 percentage points higher by the end of the sample. Similarly, the estimated coefficient on bank credit implies a correspondingly large growth effect. That is, a one-standard-deviation increase in bank credit $(0.5)$ would increase growth by 0.7 percentage points per year $\left(1.3^{*} 0.5\right)$. Taken together, the results imply that if a country had increased both stock market liquidity and bank development by one standard deviation, then by the end of the 18-year sample period, real per capita GDP would have been almost 30 percent higher and productivity would have been almost 25 percent higher. ${ }^{3}$

Critically for policymakers, LZ do not find that stock market size, as measured by market capitalization divided by GDP, is robustly correlated with growth. Simply listing on the national stock exchange does not necessarily foster resource allocation. Rather, it is the ability to trade ownership of the economy's productive technologies that influences resource allocation and growth.

While LZ incorporate stock markets into the analysis of economic growth, there are problems.

3 As emphasized throughout, these conceptual experiments do not consider the question of causality or how to change the operation of the financial sector 
First, they do not deal formally with the issue of causality. Second, while LZ (1998) include stock markets, they exclude other components of the financial sector, e.g., bond markets and the financial services provided by nonfinancial firms. Third, as discussed above, the turnover ratio may not accurately measure the ability to trade shares and may miss other important services provided by equity markets.

\section{Using Instrumental Variables To Deal with Simultaneity Bias}

To assess whether the finance-growth relationship is driven by simultaneity bias, recent research uses instrumental variables to extract the exogenous component of financial development. To do this, one needs instrumental variables that explain crosscountry differences in financial development but are uncorrelated with economic growth beyond their link with financial development. Then, one can use standard instrumental variable procedures to examine the finance-growth relationship while formally controlling for endogeneity.

Levine $(1998,1999)$ and Levine, Loayza, and Beck (2000) use the La Porta, Lopez-de-Silanes, Shleifer, and Vishny (1998) (henceforth LLSV) measures of legal origin as instrumental variables. In particular, LLSV show that legal origin - whether a country's commercial/company law derives from British, French, German, or Scandinavian lawimportantly shapes national approaches to laws concerning creditors and the efficiency with which those laws are enforced. Since finance is based on contracts, legal origins that produce laws that protect the rights of external investors and enforce those rights effectively will do a correspondingly better job at promoting financial development. Indeed, LLSV trace the effect of legal origin to laws and enforcement and then to the development of financial intermediaries. Since most countries obtained their legal systems through occupation and colonization, the legal origin variables may be plausibly treated as exogenous.

Formally, consider the generalized method of moments (GMM) regression:

$$
G_{j}=a+b F_{i}+c X+u .
$$

$G_{j}$ is real per capita GDP growth over the 1960-95 period. The legal origin indicators are used as instrumental variables for the measures of financial development, $F_{i} . X$ is treated as an included exogenous variable.

The validity of the instrumental variables, the legal origin dummy variables, requires that they are uncorrelated with the error term, $u$, i.e., they may affect growth only through the financial development indicators and the variables in the conditioning information set, $X$. I test the null hypothesis that the instrumental variables are uncorrelated with the error term using Hansen's (1982) test of the overidentifying restrictions (OIR-test). If the regression specification "passes" the test, then we cannot reject the statistical and economic significance of the estimated coefficient on financial intermediary development as indicating an effect running from financial development to per capita GDP growth.

In using instrumental variables, Levine, Loayza, and Beck (2000) and Beck, Levine, and Loayza (2000) also develop a new measure of overall financial development. The new measure, private credit, equals the value of credits by financial intermediaries to the private sector divided by GDP. The measure (i) isolates credit issued to the private sector, (ii) excludes credit issued to governments, government agencies, and public enterprises, and (iii) excludes credits issued by central banks. Unlike the LZ bank credit measure, private credit includes credits issued by financial intermediaries that are not classified as deposit money banks by the International Monetary Fund.

As shown in Table 4 (IV cross-country), Beck, Levine, and Loayza (2000) find a very strong connection between the exogenous component of financial intermediary development and long-run economic growth when using cross-country instrumental variables. They also show that the exogenous component of financial development is linked with both capital accumulation and productivity growth. Using various conditioning information sets, i.e., different $X$ 's, the results still hold. Furthermore, the data do not reject Hansen's (1982) test of the overidentifying restrictions. Thus, the exogenous component of privately owned banks is positively associated with economic growth

These results suggest an economically large impact of financial development on growth. For example, India's value of private credit over the period 1960-95 was 19.5 percent of GDP, while the mean value for developing countries was 25 percent of GDP. The estimated coefficient suggests that an exogenous improvement in private credit in India 


\section{Table 4}

Growth, Productivity Growth, and Capital Accumulation, Panel GMM and OLS, 1960-95

\begin{tabular}{llllll} 
Estimation procedure & $\begin{array}{c}\text { Private } \\
\text { credit }\end{array} \quad$ Countries & Observations & OIR test ${ }^{1}$ & $\begin{array}{c}\text { Sargan test } \\
(p-v a l u e)\end{array}$ & $\begin{array}{c}\text { Serial } \\
\text { correlation test }^{3} \\
(p-v a l u e)\end{array}$ \\
\hline
\end{tabular}

A. Dependent variable: real per capita GDP growth

$\begin{array}{lccccc}2.22^{* *} & 63 & 63 & 0.577 & & \\ & (0.003) & & & & \\ \text { GM cross-country } & 2.40^{* *} & 77 & 365 & 0.183 & 0.516 \\ (0.001) & & & \end{array}$

B. Dependent variable: productivity growth

$\begin{array}{lrrrrr}1.50 * * & 63 & 63 & 2.036 & & \\ & (0.004) & & & & \\ \text { GMM panel } & 1.33^{* *} & 77 & 365 & 0.205 & 0.772 \\ (0.001) & & & \end{array}$

C. Dependent variable: capital per capita growth

\begin{tabular}{|c|c|c|c|c|c|c|}
\hline IV cross-country & $\begin{array}{c}2.83^{* *} \\
(0.006)\end{array}$ & 63 & 63 & 6.750 & & \\
\hline GMM panel & $\begin{array}{c}3.44^{* *} \\
(0.001)\end{array}$ & 77 & 365 & & 0.166 & 0.014 \\
\hline
\end{tabular}

NOTE: **Indicates significance at the 5 percent level; $p$-values are in parentheses.

${ }^{1}$ The null hypothesis is that the instruments used are not correlated with the residuals from the respective regression. Critical values for OIR test $(2$ d.f.): 10 percent $=4.61 ; 5$ percent $=5.99$.

${ }^{2}$ The null hypothesis is that the instruments used are not correlated with the residuals from the respective regression.

${ }^{3}$ The null hypothesis is that the errors in the first-difference regression exhibit no second-order serial correlation.

IV cross-country = cross-country instrumental variables with legal origin as instruments, estimated using GMM; GMM panel = dynamic panel (5-year averages) generalized method of moments using system estimator; private credit = logarithm (credit by deposit money banks and other financial institutions to the private sector divided by GDP). Other explanatory variables: logarithm of initial income per capita, average years of schooling.

SOURCE: Beck, Levine, and Loayza (2000).

that would have pushed it to the sample mean for developing countries would have accelerated real per capita GDP growth by an additional 0.6 percentage points per year. These types of conceptual experiments must be treated as illustrative because they do not account for how to increase financial intermediary development.

While these analyses confront the causality issue, problems remain. In addition to the previously noted problems of constructing accurate measures of financial development, these cross-country instrumental variable analyses consider only the endogenous determination of the financial development. They treat the other explanatory variables as exogenous. Furthermore, the cross-country instrumental variable studies do not simultaneously consider the independent role of equity markets.

\section{PANEL STUDIES OF FINANCE AND GROWTH}

\section{Why Use Panel Techniques?}

In light of the problems associated with purely cross-country growth regressions, Levine, Loayza, and Beck (2000) (henceforth LLB) use a GMM estimator developed for panel data (Arellano and Bond, 1991, and Arellano and Bover, 1995). Compared with purely cross-country approaches, the panel 
approach has three important advantages and one particular disadvantage. To see these, consider the panel regression specified as follows:

$$
y_{i, t}=a X_{i, t}^{1}+b X_{i, t}^{2}+C_{i}+T_{t}+u_{i, t}
$$

where $y$ represents growth, $X^{1}$ represents a set of lagged explanatory variables, and $X^{2}$ represents a set of contemporaneous explanatory variables, $C$ is an unobserved country-specific effect, $T$ is a timespecific effect, $u$ is the time-varying error term, and $i$ and $t$ represent country and (five-year) time period, respectively.

The first benefit from moving to a panel is the ability to exploit the time-series and cross-sectional variation in the data. LLB construct a panel that consists of data for 77 countries over the period 1960-95. The data are averaged over seven nonoverlapping five-year periods. Moving to a panel incorporates the variability of the time-series dimension, exploiting substantial additional variability.

A second benefit from moving to a panel is that in the purely cross-sectional regression, the unobserved country-specific effect is part of the error term so that correlation between $C_{i}$ and the explanatory variables results in biased coefficient estimates. ${ }^{4}$ To control for the presence of unobserved country-specific effects, Arellano and Bond (1991) propose to "first-difference" the regression equation to eliminate the country-specific effect and then use instrumental variables to control for endogeneity. This approach eliminates biases due to country-specific omitted variables.

The third benefit from using a panel is that it overcomes the following problem: the pure crosscountry instrumental variable does not control for the potential endogeneity of all the regressors. This problem can lead to inappropriate inferences on the coefficient on financial development. The panel estimator uses instruments based on previous realizations of the explanatory variables to consider the potential endogeneity of the other regressors.

An important disadvantage caused by moving to panel data is that it means employing data averaged over five-year periods. Yet, we are seeking to assess the connection between financial development and long-run growth. To the extent that five years does not adequately proxy for long-run growth, the panel methods may be less precise in assessing

\footnotetext{
4 Furthermore, if the lagged dependent variable is included in $X^{1}$ (which is the norm in cross-country regressions), then the country-specific effect is certainly correlated with $X^{1}$.
}

the finance-growth relationship than methods based on lower-frequency data.

\section{Results with Financial Intermediation}

LLB use panel techniques to study the relationship between financial intermediary development and growth, while Beck, Levine, and Loayza (2000) extend this work to evaluate the relationship between financial development and the sources of growth, i.e., productivity growth and physical capital accumulation. They use many indicators of financial intermediary development and various conditioning information sets to assess robustness (Levine and Renelt, 1992). Table 4 summarizes these results using the private credit measure of financial development described above.

Table 4 indicates a positive relationship between the exogenous component of financial development and economic growth, productivity growth, and capital accumulation. The regressions pass the standard specification tests for panel regressions. Remarkably, the coefficient estimates for the panel estimates are very similar to those obtained using pure cross-sectional instrumental variables. Thus, the large, positive relationship between economic growth and private credit does not appear to be driven by simultaneity bias, omitted country-specific effects, or other problems plaguing cross-country growth regressions. ${ }^{5}$

\section{Stock Markets, Banks, and Growth Revisited}

Rousseau and Wachtel (2000) extend the LZ study of stock markets, banks, and growth to a panel context. They use annual data and the panel difference estimator proposed by Arellano and Bond (1991). Thus, they jointly study the impact of bank and equity markets on economic growth.

Beck and Levine (forthcoming) build on Rousseau and Wachtel (2000). Beck and Levine (i) use data averaged over five-year periods to abstract from business-cycle fluctuations, (ii) employ more recent panel procedures that avoid biases associated with difference, and (iii) extend the sample through 1998, which mitigates the potential effect of the Asian stock market boom in the 1990s on the results.

\footnotetext{
5 Beck, Levine, and Loayza (2000) go on to argue that the finance-capital accumulation link is not robust to alternative specifications, but financial development is robustly linked with both economic growth and productivity growth
} 


\section{Table 5}

Stock Markets, Banks, and Growth: Panel GMM and OLS, 1975-98

\begin{tabular}{lcccccc} 
& Bank & Countries & Observations & $\begin{array}{c}\text { Sargan test } \\
\text { (p-value) }\end{array}$ & $\begin{array}{c}\text { Serial } \\
\text { correlation test }^{2} \\
(\mathbf{p} \text {-value) }\end{array}$ \\
\hline OLS cross-country & $1.47^{* *}$ & $0.79^{* *}$ & 40 & & & \\
& $(0.001)$ & $(0.025)$ & & & \\
GMM panel & $1.76^{* *}$ & $0.96^{* *}$ & 40 & 146 & 0.488 & 0.60 \\
& $(0.001)$ & $(0.001)$ & & &
\end{tabular}

NOTE: **Indicates significance at the 5 percent level; $p$-values are in parentheses.

${ }^{1}$ The null hypothesis is that the instruments used are not correlated with the residuals.

${ }^{2}$ The null hypothesis is that the errors in the first-difference regression exhibit no second-order serial correlation.

OLS = ordinary least squares with heteroskedasticity-consistent standard errors; GMM = dynamic panel generalized method of moments using system estimator; bank credit = logarithm (credit by deposit money banks to the private sector as a share of GDP); turnover = logarithm (value of the trades of domestic shares on domestic exchanges as a share of market capitalization of domestic shares). Other explanatory variables: logarithm of initial income, logarithm of initial secondary school enrollment.

SOURCE: Beck and Levine (forthcoming, Tables 2 and 3).

Table 5 indicates that the exogenous components of both stock market development and bank development help predict economic growth. Based on Beck and Levine (forthcoming), Table 5 also presents simple ordinary least-squares (OLS) regressions. As shown, the coefficient estimates from the two methods are very similar. The panel procedure passes the standard specification tests, which increases confidence in the assumptions underlying the econometric methodology. While not shown, Beck and Levine (forthcoming) find that stock market capitalization is not closely associated with growth, which confirms the earlier results by LZ. Thus, it is not listing, per se, that is important for growth; rather, it is the ability of agents to exchange ownership claims on an economy's productive technologies that matters.

The Table 5 estimates are economically meaningful and consistent with magnitudes obtained using different methods. If Mexico's turnover ratio had been at the average of the Organisation for Economic Cooperation and Development (OECD) countries (68 percent) instead of the actual 36 percent during the period 1996-98, it would have grown 0.6 percentage points faster per year. Similarly, if its bank credit had been at the average of all OECD countries (71 percent) instead of the actual 16 percent, it would have grown 0.6 percentage points faster per year. These results suggest that the exogenous components of both bank and stock market development have an economically large impact on economic growth. Note, however, using quarterly data and vector autoregressive techniques, Arestis, Demetriades, and Luintel (2001) find that the economic effect of stock market liquidity on growth is positive and significant, but smaller economically than that found in LZ, Rousseau and Wachtel (2000), and Beck and Levine (forthcoming). While differences in data frequency, country coverage, sample period, and econometric technique may account for the differences, future work needs to clarify the economic impact of stock market development on economic growth.

\section{MICROECONOMIC STUDIES OF FINANCE AND GROWTH}

Industry-level and firm-level data have also been brought to bear on the question of whether financial development promotes economic growth. By circumventing weaknesses with cross-country and panel studies, the microeconomic research seeks to resolve causality issues and to document in greater detail the mechanisms, if any, through which finance influences economic growth.

\section{Industry-Level Studies}

In a very influential study, Rajan and Zingales (1998) (henceforth RZ) use industry-level data to study the mechanisms through which financial development may influence economic growth and to deal rigorously with causality issues. They argue 
that better-developed financial systems ameliorate market frictions that make it difficult for firms to obtain external finance. Thus, industries that are naturally heavy users of external finance should benefit disproportionately more from greater financial development than industries that are not naturally heavy users of external finance. If researchers can identify those industries that rely heavily on external finance in an economy with few market frictions-i.e., "naturally heavy users" of external finance - then this establishes a natural test: Do industries that are naturally heavy users of external finance grow faster in economies with better developed financial systems? If they do, then this supports the view that financial development spurs growth by facilitating the flow of external finance.

RZ work under three maintained assumptions: (i) financial markets in the United States are relatively frictionless, (ii) in a frictionless financial system, technological factors influence the degree to which an industry uses external finance, and (iii) the technological factors influencing external finance are reasonably constant across countries. $\mathrm{RZ}$ use the external financing of industries in the United States as a benchmark of the external financing needs of industries in a comparatively frictionless financial system. They then develop methods to assess whether industries that are naturally heavy users of external finance grow comparatively faster in countries that are more financially developed.

Consider the equation

$$
\begin{aligned}
& \text { Growth }_{i, k}= \\
& a C+b I+\text { Share }_{i, k}+d\left[\text { External }_{k}{ }^{*} F D_{i}\right]+u_{i, k} .
\end{aligned}
$$

Growth $_{i, k}$ is the average annual growth rate of value added in industry $k$ and country $i$ over the period 1980-90. $C$ and $I$ are matrices of country and industry dummies for all countries and industries, respectively. Share $e_{i, k}$ is the share of industry $k$ in manufacturing in country $i$ in 1980. External $_{k}$ is the fraction of capital expenditures not financed with internal funds for U.S. firms in industry $k$ between 1980-90. $F D_{i}$ is an indicator of financial development for country $i$. RZ interact the external dependence of an industry (External) with financial development $(F D)$, where the estimated coefficient on the interaction, $d$, is the focus of their analysis. Thus, if $d$ is significant and positive, then this implies that an increase in financial development $(F D)$ will induce a bigger impact on industrial growth $\left(\right.$ Growth $\left._{i, k}\right)$ if this industry relies heavily on exter- nal finance $\left(\right.$ External $\left._{k}\right)$ than if this industry is not a naturally heavy user of external finance. ${ }^{6}$

This approach allows RZ (i) to study a particular mechanism, external finance, through which finance operates rather than simply assess links between finance and growth and (ii) to exploit within-country differences concerning industries.

RZ use data on 36 industries across 41 countries. To measure financial development, RZ examine (i) total capitalization, which equals the summation of stock market capitalization and domestic credit as a share of GDP, and (ii) accounting standards. As $\mathrm{RZ}$ discuss, there are problems with these measures. Stock market capitalization does not capture the actual amount of capital raised in equity markets. ${ }^{7}$ RZ use the accounting standards measure as a positive signal of the ease with which firms can raise external funds, while noting that it is not a direct measure of external financing. Beck and Levine (2002) confirm the RZ findings by using alternative measures of financial development.

As summarized in Table 6, RZ find that the coefficient estimate for the interaction between external dependence and total capitalization measure, External ${ }_{k}{ }^{*}$ Total Capitalization $_{i}$, is positive and statistically significant at the 1 percent level. This implies that an increase in financial development disproportionately boosts the growth of industries that are naturally heavy users of external finance.

$\mathrm{RZ}$ note that the economic magnitude is large. Compare the machinery industry with the beverage industry. The former is an industry with a dependence of 0.45 and is at the 75 th percentile of the sample; the latter has low dependence, 0.08 , and is at the 25th percentile. Now, consider Italy, which has high total capitalization (0.98) and is at the 75th percentile, and the Philippines, which has a capitalization value of 0.46 and is at the 25 th percentile of

\footnotetext{
6 They do not include financial development independently because they focus on within-country, within-industry growth rates. The dummy variables for industries and countries correct for country - and industryspecific characteristics that might determine industry growth patterns. $\mathrm{RZ}$ thus isolate the effect that the interaction of external dependence and financial development/structure has on industry growth rates relative to country and industry means. By including the initial share of an industry, this controls for a convergence effect: industries with a large share might grow more slowly. RZ include the share in manufacturing, rather than the level, to focus on within-country, withinindustry growth rates.

7 Indeed, some countries provide tax incentives for firms to list, which artificially boosts stock market capitalization without indicating greater external financing or stock market development. Also, as discussed above, stock market capitalization does not necessarily reflect how well the market facilitates exchange.
} 


\section{Table 6}

Industry Growth and Financial Development

Dependent variable: growth of value added of industy $k$ in country $i, 1980-90$

\begin{tabular}{|c|c|c|c|c|}
\hline $\begin{array}{c}\text { Share }_{i, k} \text { of industry } k \\
\text { in country } i \text { in } 1980\end{array}$ & $\begin{array}{c}\text { External }_{\boldsymbol{k}}^{*} \\
\text { total capitalization }_{\boldsymbol{i}}\end{array}$ & $\begin{array}{c}\text { External }_{\boldsymbol{k}}{ }^{*} \\
\text { accounting standards }_{\boldsymbol{i}}\end{array}$ & $\mathbf{R}^{2}$ & Observations \\
\hline $\begin{array}{c}-0.912 \\
(0.246)\end{array}$ & $\begin{array}{c}0.069 \\
(0.023)\end{array}$ & & 0.29 & 1217 \\
\hline $\begin{array}{l}-0.643 \\
(0.204)\end{array}$ & & $\begin{array}{c}0.155 \\
(0.034)\end{array}$ & 0.35 & 1067 \\
\hline
\end{tabular}

NOTE: The table above reports the results from the regression: Growth $_{i, k}=a C+b l+\mathrm{cShare}_{i, k}+d\left[\right.$ External $\left._{k}{ }^{*} F D_{i}\right]+u_{i, k}$. Two regressions are reported corresponding to two values of $F D_{i}$, total capitalization, and account standards, respectively; heteroskedasticity-robust standard errors are in parentheses.

External $_{k}=$ the fraction of capital expenditures not financed with internal funds for U.S. firms in industry $k$ between 1980-90; total capitalization $=$ stock market capitalization plus domestic credit; accounting standards $=$ an index of the quality of corporate financial reports.

SOURCE: Rajan and Zingales (1998, Table 4).

total capitalization. Due to differences in financial development, the coefficient estimates predict the following about faster growth in the machinery industry compared with the beverages industry: This difference in growth between the two industries is predicted to be 1.3 percent faster in Italy than in the Philippines. The actual difference is 3.4 , so the estimated value of 1.3 is substantial. Thus, financial development has a big impact on industrial growth by facilitating external finance.

\section{Firm-Level Studies}

Demirgüç-Kunt and Maksimovic (1998) (henceforth DM) use firm-level data and test whether financial development influences the degree to which firms are constrained from investing in profitable growth opportunities. They focus on the use of long-term debt and external equity in funding firm growth. As in RZ, DM focus on a particular mechanism through which finance influences growth:

Does greater financial development remove impediments to firm growth? In contrast to RZ, DM estimate the external financing needs of each individual firm in the sample.

Questioning the assumptions underlying RZ, DM argue that it is important to allow for differences among countries in the amount of external financing needed by firms in the same industry. These differences may arise because firms in different countries employ different technologies, because profit rates may differ across countries, or because investment opportunities and demand may differ.
To control for differences in the need for external finance at the firm level, DM calculate the rate at which each firm can grow using (i) only its internal funds and (ii) only its internal funds and short-term borrowing. They then compute the percentage of firms that grow at rates that exceed each of these two estimated rates. This yields estimates of the proportion of firms in each economy that rely on external financing to grow.

For the largest publicly traded manufacturing firms in 26 countries, DM estimate a firm's potential growth rate using the textbook "percentage of sales" financial planning model. ${ }^{8}$ This approach relates a firm's growth rate of sales to its need for investment funds, based on three simplifying assumptions. First, the ratio of assets used in production to sales is constant. Second, the firm's profits per unit of sales are constant. Finally, the economic depreciation rate equals the accounting depreciation rate.

Based on these important maintained assumptions, DM compute the short-term financed growth rate, $S T F G_{t}$, as the maximum growth rate that can be obtained if the firm reinvests all its earnings and obtains enough short-term external resources to maintain the ratio of its short-term liabilities to assets.

Then, DM calculate the proportion of firms whose growth rates exceed the estimate of the maximum growth rate that can be financed by relying only on internal and short-term financing,

8 Beck, Demirgüç-Kunt, and Levine (2001) confirm the findings using an extended sample. 


\section{Table 7}

\section{Excess Growth of Firms and External Financing}

Dependent variable: proportion of firms that grow faster than their predicted growth rate ${ }^{1}$

\begin{tabular}{ccccc} 
Market capitalization/GDP & Turnover & Bank assets/GDP & Adjusted $\mathbf{R}^{2}$ & Countries \\
\hline-0.106 & $0.311^{* * *}$ & $0.162^{* * *}$ & 0.48 & 26 \\
$(0.058)$ & $(0.072)$ & $(0.050)$ & &
\end{tabular}

NOTE: ${ }^{* * *}$ Indicates significance at the 1 percent level; White's heteroskedasticity-consistent standard errors are in parentheses.

${ }^{1}$ The proportion of firms whose growth rates exceed the estimate of the maximum growth rate that can be financed by relying only on internal and short-term financing.

Market capitalization/GDP = value of domestic equities listed on domestic exchanges as a share of GDP; turnover = total value of trades of domestic shares on domestic exchanges as a share of market capitalization. Other regressors: rate of inflation; the law and order tradition of the economy, i.e., the extent to which citizens utilize existing legal system to mediate disputes and enforce contracts; growth rate of real GDP per capita; real GDP per capita; government subsidies to private industires and public enterprises as a share of GDP; and net fixes assets divided by total assets.

Time period: The dependent variable is averaged over the 1986-91 period. All regressors are averaged over the 1980-85 period, data permitting.

SOURCE: Demirgüç-Kunt and Maksimovic (1998, Table V).

PROPORTION_FASTER. There is quite a bit of crosscountry variation in PROPORTION_FASTER. For instance, in Turkey, South Africa, and Pakistan, less than 30 percent of the firms have growth rates that exceed the estimate of the maximum growth rate that can be financed by relying only on internal and short-term financing. In contrast, in Japan, Korea, Singapore, and Thailand, PROPORTION_FASTER is greater than 50 percent. Put differently, in these latter countries, more than half the firms require longterm financing to finance their growth according to the "percentage of sales" financial planning model.

To analyze whether financial development spurs firm growth, DM run the following cross-country regressions:

$$
\text { PROPORTION_FASTER }=a+b F D_{i, t}+c C V_{i, t}+u_{i, t} \text {, }
$$

where $F D$ is a variety of measures of financial development, $C V$ is a set of control variables, and $u$ is the error term. To measure financial development, DM use (i) the ratio of market capitalization to GDP (market capitalization/GDP), (ii) turnover, which equals the total value of shares traded divided by market capitalization, and (iii) bank assets/GDP, which equals the ratio of domestic assets of deposit banks divided by GDP. Thus, DM include all domestic assets of deposit banks, not just credit to the private sector. As control variables, DM experiment with different combinations of control variables, including economic growth, inflation, the average market to book value of firms in the economy, government subsidies to firms in the economy, the net fixed assets divided by total assets of firms in the economy, the level of real per capita GDP, and the law-andorder tradition of the economy.

As summarized in Table 7, DM (1998) find that both banking system development and stock market liquidity are positively associated with the excess growth of firms. Thus, in countries with high turnover and high bank assets/GDP, a larger proportion of firms is growing at a level that requires access to external sources of long-term capital, holding other things constant. ${ }^{9}$ Note, consistent with $\mathrm{LZ}$, the size of the domestic stock markets is not related to the excess growth of firms. After conducting a wide array of robustness checks, DM conclude that the proportion of firms that grow at rates exceeding the rate at which each firm can grow with only retained earnings and short-term borrowing is positively associated with stock market liquidity and banking system size.

\section{CONCLUSION}

This paper selectively reviews recent empirical work on the relationship between financial development and economic growth. In particular, I discuss cross-country, panel, and microeconomic studies

\footnotetext{
9 Recent work examines whether bank-based or market-based financial systems are most conducive for growth (Beck, Demirgüç-Kunt, and Levine, 2001; Beck and Levine, 2002; and Levine, 2002b). While financial development boosts growth, the evidence does not favor either bank-based or market-based systems.
} 
of the finance-growth nexus. As noted in the introduction, I have largely ignored purely time-series studies and detailed country investigations that are reviewed in Levine (2002a).

There are strengths and weaknesses associated with each methodology used to examine the relationship between finance and economic growth. The cross-country work examines a broad number of countries and aggregates over long time periods and thereby focuses on long-run growth. The panel work ameliorates many statistical shortcomings associated with the cross-country work and exploits the time-series dimension of the data. In using higher-frequency data, however, the panel work is less directly linked to long-run growth and may not fully abstract from business-cycle and shorter-run influences. The microeconomic evidence examines particular channels through which finance may influence economic activity and deals with causality concerns. However, the microeconomic studies operate under a number of maintained hypotheses, the validity of which are difficult to ascertain. Finally, one problem plaguing the entire study of finance and growth pertains to the proxies for financial development. While theory suggests that financial systems influence growth by easing information and transactions costs and thereby improving the allocation of capital, corporate governance, risk management, and financial exchanges, the empirical measures do not directly measure these financial functions.

While the different methodologies have distinct strengths and weaknesses, they produce remarkably consistent results. The main conclusions that I garner from recent empirical work are as follows:

- Countries with better-developed financial systems tend to grow faster. Specifically, both financial intermediaries and markets matter for growth. The size of the banking system and the liquidity of stock markets are each positively linked with economic growth.

- Simultaneity bias does not seem to be the cause of this result.

- Better-functioning financial systems ease the external financing constraints that impede firm and industrial expansion. Thus, one channel through which financial development matters for growth is access to external capital, which enables industries and firms to expand.

I state these conclusions simply, but stress that
I hold them with a significant degree of skepticism. These findings may certainly be refuted, qualified, and clarified by future work, and I have listed various avenues for future research in the text. Nevertheless, my assessment for now is that a large - albeit not unanimous - body of evidence supports these three conclusions.

To the extent that financial systems exert a first-order influence on economic growth, this motivates research into the determinants of wellfunctioning financial systems. A new and exciting literature researches this question. Some focus on the direct laws and regulations shaping the operation of financial systems, while complementary work examines the broader political, historical, and institutional determinants of financial development.

In terms of direct laws and regulations, a growing body of work examines how the law and enforcement mechanisms protecting outside investors influence stock markets, banks, and economic growth (LLSV; Beck, Demirgüç-Kunt, and Levine, forthcoming). In other work, La Porta, Lopez-de-Silanes, and Shleifer (2002) argue that government ownership of banks hurt the efficient functioning of the banking system and hence economic growth. Barth, Caprio, and Levine (forthcoming) and others examine the role of bank regulations and supervisory practices on the operation of banks and, hence economic growth (Jayaratne and Strahan, 1996; Demirgüç-Kunt, Laeven, and Levine, 2002; Beck, Demirgüç-Kunt, and Levine, forthcoming). In terms of international issues, Levine (2002c) finds that regulatory restrictions on foreign bank entry hurt the efficiency of bank operations. Furthermore, Bekaert, Harvey, and Lundblad (2001) show that international financial liberalization improves the operations of financial systems with positive effects on economic growth. But, Levine and Schmukler (2002) find that international cross-listing by emerging market firms can hurt the operation of the emerging market itself, with adverse implications for economic development (Guiso, Sapienza, and Zingales, 2002). As a final example of work examining specific policies, some research highlights the importance of inflation on the functioning of stock markets and banks (Boyd, Levine, and Smith, 2001).

More broadly, some research studies the underlying forces shaping the laws, regulations, and institutions that form the "rules of the game" governing financial arrangements. Rajan and Zingales (2002 and 2003a,b) and Pagano (2001) focus on how political-economy forces induce governments to 
repress or encourage financial development, while Guiso, Sapienza, and Zingales (2000) examine the role of social capital in shaping financial systems. Finally, some scholars stress the role of geographical endowments on the formation of long-lasting institutions that shape financial systems (Engerman and Sokoloff, 1997; Acemoglu, Johnson, and Robinson, 2001; Beck, Demirgüç-Kunt, and Levine, 2002;

Easterly and Levine, 2003). This work is building a wide-array of evidence on which laws, regulations, and policies work best to promote growth-enhancing financial systems and on the political and historical determinants of financial systems.

\section{REFERENCES}

Acemoglu, Daron; Johnson, Simon and Robinson, James A

"The Colonial Origins of Comparative Development: An Empirical Investigation.” American Economic Review, December 2001, 91(5), pp. 1369-401.

Arellano, Manuel and Bond, Stephen. "Some Tests of Specification for Panel Data: Monte Carlo Evidence and an Application to Employment Equations." Review of Economic Studies, April 1991, 58(2), pp. 277-97.

and Bover, Olympia. "Another Look at the Instrumental-Variable Estimation of Error-Components Models." Journal of Econometrics, July 1995, 68(1), pp. 29-51.

Arestis, Philip; Demetriades, Panicos O. and Luintel, Kul B. "Financial Development and Economic Growth: The Role of Stock Markets." Journal of Money, Credit, and Banking, February 2001, 33(1), pp. 16-41.

Atje, Raymond and Jovanovic, Boyan. "Stock Markets and Development.” European Economic Review, April 1993, 37(2-3), pp. 632-40.

Bagehot, Walter. Lombard Street, A Description of the Money Market. Homewood, IL: Richard D. Irwin, 1873 (1962 Edition).

Barth, James; Caprio, Gerard and Levine, Ross. "Regulation and Supervision of Banks: What Works Best?" Journal of Financial Intermediation (forthcoming).

Beck, Thorsten; Demirgüç-Kunt, Asli and Levine, Ross "The Financial Structure Database," in A. Demirgüç-Kunt and R. Levine, eds., Financial Structure and Economic Growth: A Cross-Country Comparison of Banks, Markets, and Development. Cambridge, MA: MIT Press, 2001. and "Bank

Supervision and Firm Access to Credit." Unpublished manuscript, University of Minnesota, 2002.

and "Law and

Finance: Why Does Legal Origin Matter?” Journal of Comparative Economics (forthcoming).

and Levine, Ross. "Industry Growth and Capital Allocation: Does Having a Market- or Bank-Based System Matter?" Journal of Financial Economics, May 2002, 64(2), pp. 147-80.

and "Stock Markets, Banks, and Growth: Panel Evidence." Journal of Banking and Finance (forthcoming). and Loayza, Norman. "Finance and the Sources of Growth." Journal of Financial Economics, October-November 2000, 58(1-2), pp. 261-300.

Bekaert, Geert; Harvey, Campbell R. and Lundblad, Christian T. "Does Financial Liberalization Spur Growth?" NBER Working Paper No. 8245, National Bureau of Economic Research, April 2001.

Bencivenga, Valerie R.; Smith, Bruce D. and Starr, Ross M. "Transactions Costs, Technological Choice and Endogenous Growth." Journal of Economic Theory, October 1995, 67(1), pp. $153-77$.

Bhide, Amar. "The Hidden Costs of Stock Market Liquidity." Journal of Financial Economics, August 1993, 34(1), pp. 31-51.

Boyd, John H.; Levine, Ross and Smith, Bruce D. "The Impact of Inflation on Financial Sector Performance." Journal of Monetary Economics, April 2001, 47(2), pp. 221-48.

Demirgüç-Kunt, Asli; Laeven, Luc and Levine, Ross. "The Impact of Bank Regulations, Concentration, and Institutions on Bank Efficiency." Unpublished manuscript, University of Minnesota, 2002.

and Levine, Ross. Financial Structure and Economic Growth: A Cross-Country Comparison of Banks, Markets, and Development. Cambridge, MA: MIT Press, 2001.

and Maksimovic, Vojislav. "Law, Finance, and Firm Growth.” Journal of Finance, December 1998, 53(6), pp. 2107-37. 
Easterly, William and Levine, Ross. "Tropics, Germs, and Crops: How Endowments Influence Economic Development." Journal of Monetary Economics, January 2003, 50(1), pp. 3-39.

Engerman, Stan and Sokoloff, Kenneth. "Factor Endowments, Institutions, and Differential Paths of Growth Among New World Economies: A View from Economic Historians of the United States," in S.H. Haber, ed., How Latin America Fell Behind: Essays on the Economic Histories of Brazil and Mexico, 1800-1914. Stanford: Stanford University Press, 1997, pp. 260-304.

Goldsmith, Raymond W. Financial Structure and Development. New Haven, CT: Yale University Press, 1969.

Guiso, Luigi; Sapienza, Paola and Zingales, Luigi. “The Role of Social Capital in Financial Development," NBER Working Paper No. w7563, National Bureau of Economic Research, February 2000. and "Does Local

Financial Development Matter?” NBER Working Paper No. w8923, National Bureau of Economic Research, May 2002 .

Gurley, John G. and Shaw, Edward S. "Financial Aspects of Economic Development." American Economic Review, September 1955, 45(4), pp. 515-38.

Hansen, Lars P. "Large Sample Properties of Generalized Method of Moments Estimators." Econometrica, July 1982, 50(4), pp. 1029-54.

Jayaratne, Jith and Strahan, Philip E. "The Finance-Growth Nexus: Evidence from Bank Branch Deregulation." Quarterly Journal of Economics, August 1996, 111(3), pp. 639-70.

King, Robert G. and Levine, Ross. "Financial Intermediation and Economic Development," in Colin Mayer and Xavier Vives, eds., Capital Markets and Financial Intermediation. London: Centre for Economic Policy Research, 1993a, pp. $156-89$

and _. "Finance and Growth:

Schumpeter Might Be Right." Quarterly Journal of Economics, August 1993b, 108(3), pp. 717-37.

and "Finance, Entrepreneurship, and Growth: Theory and Evidence." Journal of Monetary Economics, December 1993c, 32(3), pp. 513-42.
La Porta, Rafael; Lopez-de-Silanes, Florencio and Shleifer, Andrei. "Government Ownership of Banks." Journal of Finance, February 2002, 57(1), pp. 265-301. and Vishny,

Robert W. "Law and Finance." Journal of Political Economy, December 1998, 106(6), pp. 1113-55.

Levine, Ross. "Stock Markets, Growth, and Tax Policy." Journal of Finance, September 1991, 46(4), pp. 1445-65.

"Financial Development and Economic Growth: Views and Agenda." Journal of Economic Literature, June 1997, 35(2), pp. 688-726.

"The Legal Environment, Banks, and LongRun Economic Growth." Journal of Money, Credit, and Banking, August 1998, 30(3, part 2), pp. 596-613.

"Law, Finance, and Economic Growth." Journal of Financial Intermediation, January-April 1999 , 8(1-2), pp. 8-35.

"Finance and Growth." Unpublished manuscript, University of Minnesota, 2002a.

"Bank-Based Versus Market-Based Financial Systems: Which Is Better?" Journal of Financial Intermediation, October 2002b, 11(4), pp. 398-428.

"Denying Foreign Bank Entry: Implication for Bank Interest Margins." Unpublished manuscript, University of Minnesota, 2002c.

; Loayza, Norman and Beck, Thorsten.

"Financial Intermediation and Growth: Causality and Causes.” Journal of Monetary Economics, August 2000, 46(1), pp. 31-77.

and Renelt, David. "A Sensitivity Analysis of Cross-Country Growth Regressions." American Economic Review, September 1992, 82(4), pp. 942-63.

and Schmukler, Sergio. "Liquidity Spillover." Unpublished manuscript, University of Minnesota, 2002. and Zervos, Sara. "Stock Markets, Banks, and Economic Growth.” American Economic Review, June 1998, 88(3), pp. 537-58.

Lucas, Robert E. Jr. "On the Mechanics of Economic Development." Journal of Monetary Economics, July 1988, 22(1), pp. 3-42. 
McKinnon, Ronald I. Money and Capital in Economic Development. Washington, DC: Brookings Institution, 1973.

Meier, Gerald M. and Seers, Dudley. Pioneers in Development. New York: Oxford University Press, 1984.

Miller, Merton H. "Financial Markets and Economic Growth." Journal of Applied Corporate Finance, Fall 1998, 11(3), pp. 8-14.

Pagano, Marco and Volpin, Paolo. "The Political Economy of Finance." Oxford Review of Economic Policy, Winter 2001, 17(4), pp. 502-19.

Rajan, Raghuram G. and Zingales, Luigi. "Financial Dependence and Growth." American Economic Review, June 1998, 88(3), pp. 559-86.

and "Banks and Markets: The Changing Character of European Finance.” Unpublished manuscript, University of Chicago, October 2002.

and Saving Capitalism from the Capitalists: Unleashing the Power of Financial Markets To Create Wealth and Spread Opportunity. New York: Crown Business, 2003a.

and "The Great Reversals: The

Politics of Financial Development in the Twentieth Century." Journal of Financial Economics, July 2003b, 69(1).

Rousseau, Peter L. and Wachtel, Paul. "Equity Markets and Growth: Cross-Country Evidence on Timing and Outcomes, 1980 1995." Journal of Banking and Finance, December 2000, 24(12), pp. 1933-57.

Schumpeter, Joseph A. Theorie der Wirtschaftlichen Entwicklung. Leipzig: Dunker \& Humblot, 1912 [The Theory of Economic Development: An Inquiry into Profits, Capital, Interest, and the Business Cycle, translated by Redvers Opie. Cambridge, MA: Harvard University Press, 1934]. 